\title{
UW-NPS WILDERNESS INTERNSHIP
}

\section{SHANNON GLENDENNING $\uparrow$ UNIVERSITY OF WYOMING $\uparrow$ LARAMIE, WY}

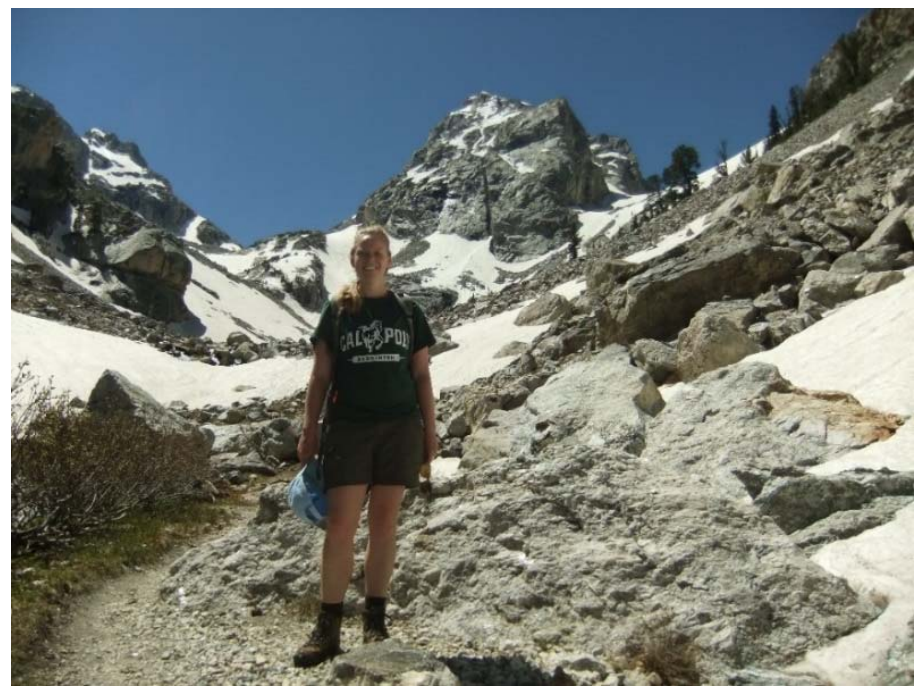

\section{INTRODUCTION}

In the summer of 2013, projects regarding wilderness in the John D. Rockefeller, Jr., Memorial Parkway (Parkway) and Grand Teton National Park (Park) were researched and completed. The researcher worked under the direct supervision of Shan Burson, bioacoustics ecologist and wilderness coordinator for Grand Teton National Park, and with the staff of the Science and Resource Management Division of Grand Teton National Park. The main goal of the wilderness internship was the drafting of a wilderness eligibility assessment for the Parkway. Secondary tasks included research and recommendations for wilderness management in the Park.

\section{WILDERNESS ELIGIBILITY ASSESSMENT}

All lands administered by the National Park Service are evaluated for their eligibility for inclusion in the National Wilderness Preservation System. It is a first, administrative look at the wilderness character of a piece of land. Since the John D. Rockefeller, Jr., Memorial Parkway was established in 1972, an assessment was never completed. The Parkway is administered by Grand Teton National Park.

The initial steps of the study was finding and evaluating National Park Service documents relating to the establishment and management of the Parkway. Documents included the Environmental Impact Report from 1973 evaluating the impacts of the establishment of the Parkway; congressional hearings and reports on the establishment of the Parkway; the enabling legislation for the Parkway; the Foundation for Planning and Management for Grand Teton National Park and the John D. Rockefeller, Jr., Memorial Parkway; the General Management Plan; the Fire Management Plan, land management policies and designations for neighboring lands to the Parkway; visitation statistics, environmental assessments for various projects that have occurred in the Parkway; and many other documents relating to former and current management and activities occurring in the Parkway. These documents provided a basis for the assessment. 
The second component of the assessment was evaluating the Parkway based on its wilderness character using 2012 NAIP imagery at one meter resolution. This imagery was used in coordination with existing Park GIS information to determine what types and levels of development had occurred in the Parkway.

Using this information, the wilderness character of the land in the Parkway was evaluated. Wilderness character is defined in the Wilderness Act of 1964 and subsequent National Park Service policies. Based on this analysis, a draft memo was prepared explaining the assessment process and the recommendation based on the guidance provided by the Wilderness Act and National Park Service policies and guidance. This was sent to the Park Superintendent for review and action.

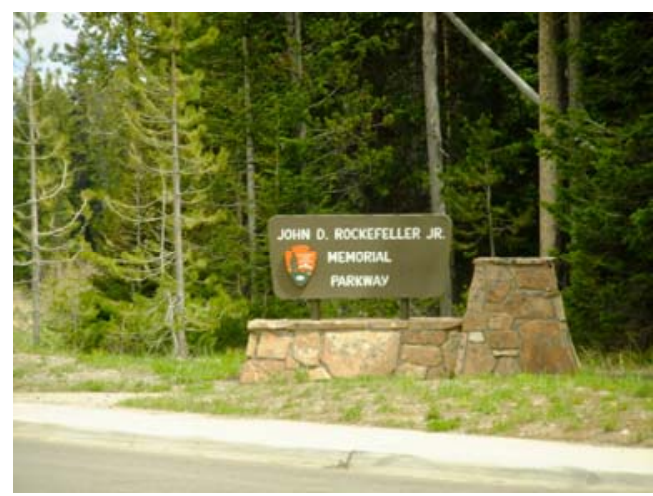

\section{OTHER WILDERNESS PROJECTS}

After the completion of the draft wilderness eligibility assessment additional work on wilderness management in Grand Teton National Park was completed. The Park does not manage any congressionally designated wilderness but manages recommended and potential wilderness, land managed to preserve its wilderness character.

For every action proposed to occur in wilderness a Minimum Requirement Assessment is required. Conducting a minimum requirement analysis follows the direction of both law and agency policy to assist land managers make better informed decisions. The Park's current Minimum Requirement Decision Guide (MRDG) was evaluated and revised as necessary based on feedback from the wilderness coordinator and review of other guides used for the same analysis. Additionally, programmatic MRDGs were developed for ongoing administrative actions occurring in Grand Teton wilderness. Drafts include bridge replacements, sign replacements, food storage installations, and administrative and historic structure repair or restoration, and research activities in wilderness.

The Park is going through an internal process of writing a document to effectively integrate wilderness character in Grand Teton National Park into park planning through monitoring and understanding the resources in wilderness. The first two chapters of this document were drafted, describing the definition of wilderness character and purpose of monitoring, and the history of the Wilderness Act and wilderness in Grand Teton National Park.

\section{CONCLUSION}

In the summer of 2013 significant work was completed for wilderness lands in Grand Teton National Park and the John D. Rockefeller, Jr., Memorial Parkway in Wyoming.

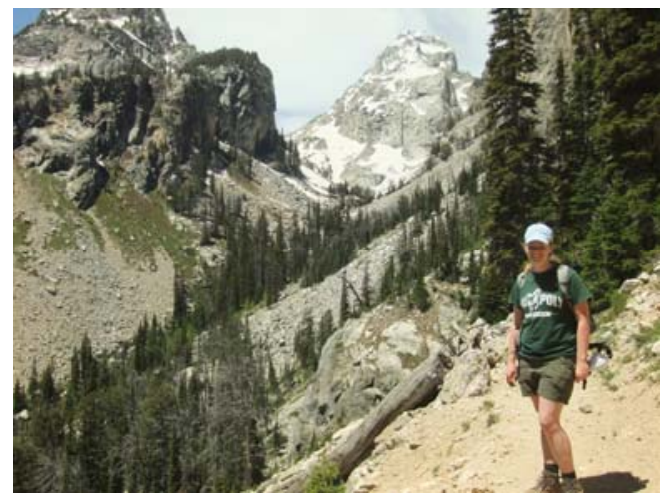

\section{ACKNOWLEDGMENTS}

I would like to thank everyone at the UWNPS Research Station. You all made the summer an amazing experience and made living in the Tetons, next to Jackson Lake, even better that I could imagine. Also a big thank you to Shan Burson and staff in the Science and Resource Management Division of Grand Teton National Park for this opportunity and great learning experience. 